\title{
REPRESENTASI KONSEP RUANG DAN WAKTU DALAM NOVEL GLONGGONG KARYA JUNAEDI SETIYONO PERSPEKTIF EKOLOGI BUDAYA
}

\author{
Sugiarti* \\ Program Studi Pendidikan Bahasa Indonesia, Fakultas Keguruan dan Ilmu Pendidikan Universitas \\ Muhammadiyah Malang, Jl. Raya Tlogomas 246 Malang, Indonesia \\ *Corresponding author: sugiarti@umm.ac.id
}

\section{INFORMASI ARTIKEL}

Sejarah Artikel

Diterima: $24 / 8 / 2019$

Direvisi: 13/12/2019

Diterima: 14/12/2019

Tersedia Daring: 31/12/2019

Kata Kunci

Dimensi Ruang dan Waktu

Ruang Publik

Lingkungan dalam dimensi sosial tidak dapat dilepaskan dengan ruang dan waktu. Ruang dan waktu menarik untuk dikaji karena di dalamnya menyimpan makna yang dalam bagi kehidupan manusia secara total. Karya sastra menjadi dokumen sosio-budaya yang merekam berbagai kondisi yang terjadi pada suatu tempat dan masa tertentu. Penelitian ini bertujuan mendeskripsikan representasi dimensi ruang dan waktu perspektif ekologi budaya. Subjek penelitian novel Glonggong karya Junaedi Setiyono. Data dikumpulkan melalui kajian pustaka dan analisis wacana pada novel Glonggong. Data dianalisis secara deskriptif kualitatif. Hasil penelitian menunjukkan bahwa representyasi ruang dapat dimaknai dalam konteks ruang publik dan ruang privat. Kedua ruang ini menyatu sehingga bersinergi untuk membangun karakter cerita secara keseluruhan yang menyaran pada pengetahuan yang dimilikinya. Representasi waktu berdimensi tidak tetap sehingga selalu terjadi perubahan dan tidak stagnan. Pada sisi inilah menempatkan ruang dan waktu tidak sesederhana yang dipahami karena keduanya memiliki cara dalam menyingkap kerahasian hidup yang bersifat mistis. Ruang dan waktu tidak pernah dianggap sebagai bentuk-bentuk murni atau bentuk kosong. Keduanya selalu berinteraksi dengan komunitas yang bergulir dengan tempat dan waktu.

\section{ABSTRACT}

Keywords

Space and Time Dimension Public Space
The environment in the social dimension cannot be separated from space and time. Space and time are interesting to study because in it saves a deep meaning for human life in total. Literacy work is a socio-cultural document that records various conditions that occur at a particular place and time. This research aims to describe representation time and space dimensions from the cultural ecologi perspective. The subject of research is Glonggong's novel by Junaedi Setiyono. Data was collected through literature review and discourse analysis. Data then analyzed qualitatively descriptive. The results of the study show that public space and private space are united so that they synergize to build the overall character of the story that is aimed at the knowledge they have. The time dimensions are not fixed so that changes always occur. Space and time is not as simple as it is understood because both have a way of revealing mystical life. Space and time are never considered pure forms of empty forms, it will always interact with the community that is rolling with time and place.

Copyright@2019, Sugiarti This is an open access article under the CC-BY-3.0 license

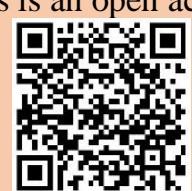

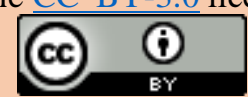




\section{PENDAHULUAN}

Masalah ruang dan waktu dalam novel Glonggong karya Junaedi Setiyono menarik untuk dikaji. Hal ini dapat diperhatikan bagaimana pengarang dalam memanfaatkan ruang dan waktu secara intens sehingga menghasilkan narasi cerita yang menarik. Pemanfaatan simbol seperti sebuah hutan jati yang meranggas, air bening, penjara, kamar sebagai representasi ruang yang bermakna dan memberikan kohesi pada tokoh yang menghuninya. Waktu memiliki relevansi gerak manusia yang tidak hanya dibatasi oleh tanda pagi, siang, sore, malam akan tetapi waktu yang selalu bergerak mengikuti pergerakan pemikiran tokoh cerita seperti Glonggong, Suta, ibu Glonggong dan tokoh-tokoh lainnya.

Dalam mengeksplorasi gagasan dan pemikirannya Junaedi Setiyono mampu memanfaatkan ruang dan waktu yang secara fisik dan kasat mata berdasarkan indra manusia. Akan tetapi, ruang dan waktu yang bersifat imajinatif. Ruang dan waktu berada pada lingkup yang tidak dapat dilepaskan dengan ekologi budaya dalam pembentukan narasi cerita. Dalam hal ini keduanya saling berhubungan karena hakikat ruang dan waktu yang selalu menyatu namun memiliki makna yang berbeda. Dengan demikian mengekplorasi dimensi ruang dan waktu dalam perspektif ekologi budaya menjadi bagian penting dalam cipta sastra perlu diungkapkan secara jelas, sehingga dapat diketahui keberadaan ruang dan waktu memiliki makna bagi kehidupan manusia.

Novel Glonggong mengungkapkan tokoh-tokoh yang hadir dengan serentetan masalah yang berada pada kondisi yang terikat oleh ruang dan waktu. Ruang yang membuat tokoh hidup tidak nyaman seperti yang dirasakan kebanyakan manusia. Waktu yang membuat tokoh merasa terbiarkan tanpa suatu kepastian. Kekuatan batiniah tokoh dalam menghadapi persoalan yang menimpa dirinya juga misteri yang berdimensi ruang dan waktu. Pada dasarnya ruang dan waktu bukalah sesuatu yang dapat diukur dan dijelaskan secara realitas manusia akan tetapi terkadang bersifat misteri bagi orang tertentu.

Oleh karena itu, untuk mengungkap keseluruhan dimensi kehidupan manusia maka manusia memiliki pemahaman terhadap kekuatan yang misterius dan mahabesar yang menguasai apa saja dalam kehidupan ini. Tidak satupun di dunia yang tidak dapat diukur----dan ukuran berarti pembatasan menurut ruang dan waktu. Dalam pemikiran mistis, ruang dan waktu tidak pernah dianggap sebagai bentuk-bentuk murni atau bentuk kosong. Keberadaanya saling bertumpang tindih, keduanya selalu berada dalam kehidupan manusia dan saling menyatu. Kehidupan manusia selalu berputar se arah putaran jarum jam. Suatu ketika di bawah ataupun di atas. Demikian pula yang dirasakan tokoh dalam novel Glonggong selalu berada pada ketidakpastian tentang hidup dan kehidupan yang sesungguhnya sehingga tokoh merasakan misteri kehidupan sebagai bagian yang harus dirasakannya meski dengan kepahitan hidup.

Disadari bahwa kehidupan tokoh menjadi suatu sistem yang saling terkait dengan lingkungan dan ekosistem yang melingkupinya. Tentunya terjadi interaksi dan interelasi antara ekologis dan ekosistem yang saling terkait. Dalam hal ini, ruang dan waktu berada pada lingkup yang tidak dapat dilepaskan dengan ekologi budaya dalam pembentukan narasi cerita. Keduanya saling berhubungan karena hakikat ruang dan waktu yang selalu menyatu namun memiliki makna yang berbeda. Junaedi Setiyono mampu memadukan ruang dan waktu menjadi dimensi hidup tokoh yang menarik dan bersifat estetik

Persoalan kemenarikan novel dapat diperhatikan bagaimana tokoh selalu ada dalam pergulatan batin ketika ia mengalami tekanan secara psikologis atas lingkungan dimana ia tinggal. Tokoh tidak merasakan kebahagiaan dalam hidupnya meski bersuami. Ruang yang dihuninya berada dalam kekosongan yang tidak berarti apapun. Tokoh hidup mengikuti waktu yang selalu bergulir tanpa makna. 
Sifat estetik dalam novel ini tampak bagaimana pengarang dalam menghadirikan tokoh dengan problem yang dihadapi melalui penggunaan simbol. Simbol tersebut dijalin dengan bahasa yang estetis seperti pada kutipan "bertemu dengan Kang Rata selepas dari penjara seperti bertemu sendang dengan air bening berkilau setelah lelah dan haus berjalan seharian mengarungi hutan jati meranggas (Setiyono, 2007). Cara pengarang memadukan ruang dan waktu menjadi estetis seperti kata bertemu ungkapan waktu, penjara representasi ruang, air bening berkilau sebagai pertanda sebuah kekuatan yang menstimulasi serta membangkitkan hidup. Setelah lelah berjalan seharian mengarungi hutan jati yang meranggas dimensi waktu dan ruang yang disajikan secara estetis.

Selanjutnya memaparkan dan menganalisis sifat khas yang terdapat pada ruang dan waktu dalam karya sastra akan memperoleh pengalaman manusia yang komplek. Dari situlah diketahui berbagai peristiwa-peristiwa menarik yang dapat digali. Melalui kajian sastra dalam perspektif budaya persoalan-persoalan yang terkait dengan ruang dan waktu yang digambarkan dalam karya sastra dan menjadi bagian penting. Dalam hal ini, akan diperoleh pengetahuan dan pemahaman cara pengarang menyajikan dunia baru.

Dalam karya sastra representasi mengacu pada bagaimana seseorang, kelompok atau gagasan atau pendapat tertentu ditampilkan sebagaimana mestinya. Menurut Wibowo (2004) bahwa representasi menunjuk pada dunia menampakkan diri tersebut dan menampakkan sebagai pertunjukkan bagi subjek penglihat atau subjek yang mengetahui. Adapun Eriyanto (dalam Bardara, 2012) mengungkapkan representasi penting dalam dua hal, apakah seseorang, kelompok, atau gagasan tersebut ditampilkan sebagaimana mestinya dan bagaimana representasi tersebut ditampilkan.

Pada dasarnya sastra tidak dapat dilepaskan dengan gejala-gejala sosial yang terjadi dalam masyarakat. Gejala-gejala tersebut bukanlah realitas tunggal dan bukan mekanisme yang bebas dari kompleksitas sistem makna. Ruang dan waktu tidak dapat direduksi dalam hukumhukum tunggal dan deterministik yang bebas konteks. Untuk menjelaskan gejala-gejala sosial tertentu tidak cukup mengamati dengan gejala-gejala yang tampak, akan tetapi dengan mempertimbangkan totalitas konteks dan lebih memperhatikan hubungan-hubungan fungsional di dalam interaksi sosial (Sugiarti, 2013).

Representasi fakta-kata kultural dalam karya sastra dapat menghuni ruang dan waktu yang tidak terbatas. Keduanya selalu berada dalam pertalian yang erat sehingga mampu menyajikan suatu narasi cerita yang mengalir. Entitas karya sastra sebagai representasi semestaan sosial berlangsung sepanjang sejarah. Tidak ada karya sastra yang sama sekali terlepas dari kehidupan sosial termasuk karya sastra yang paling absurd (Ratna, 2011). Secara khusus, narasi - dipahami sebagai representasi dari rangkaian peristiwa - didefinisikan dan dibedakan berdasarkan temporalitasnya. Sebuah korelasi diambil terutama antara waktu dan novel (Jauf, 2009).

Dengan demikian, dapat dikatakan bahwa representasi merupakan cerminan tentang segala sesuatu peristiwa dalam karya sastra yang tidak dapat dipisahkan dengan ruang dan waktu. Ruang dan waktu tidak selalu pasti akan tetapi mengalami perubahan sepanjang masa. Keduanya merupakan satu kesatuan yang hadir dan berelasi dengan konteks lingkungan budaya. Dengan mengetahui ruang dan waktu dalam persprektif budaya maka akan diperoleh pemahaman multidimensi untuk mengetahui kekuatan misterius dan mahabesar yang menguasai apa saja dalam kehidupan ini. Disadari bahwa ruang dan waktu tidaklah stagnan tetapi selalu berubah dimana ruang dan waktu tersebut difungsikan. Ruang dan waktu sesungguhnya mengarah pada representasi terhadap realitas yang bersifat imajinatif.

Dalam karya sastra representasi mengacu pada bagimana seseorang, kelompok atau gagasan atau pendapat tertentu ditampilkan sebagaimana mestinya. Menurut Wibowo (2004) bahwa representasi menunjuk pada dunia menampakkan diri tersebut dan menampakkan 
sebagai pertunjukkan bagi subjek penglihat atau subjek yang mengetahui. Adapun Eriyanto (dalam Bardara, 2012) mengungkapkan representasi penting dalam dua hal, apakah seseorang, kelompok, atau gagasan tersebut ditampilkan sebagaimana mestinya dan bagaimana representasi tersebut ditampilkan.

Pada dasarnya sastra tidak dapat dilepaskan dengan gejala-gejala sosial yang terjadi dalam masyarakat. Gejala-gejala tersebut bukanlah realitas tunggal dan bukan mekanisme yang bebas dari kompleksitas sistem makna. Gejala-gejala sosial tidak dapat direduksi dalam hukum-hukum tunggal dan deterministik yang bebas konteks. Untuk menjelaskan gejala-gejala sosial tertentu tidak cukup mengamati dengan gejala-gejala yang tampak, akan tetapi dengan mempertimbangkan totalitas konteks dan lebih memperhatikan hubungan-hubungan fungsional di dalam interaksi sosial (Sugiarti, 2013).

Dengan demikian, dapat diungkapkan bahwa representasi merupakan cerminan tentang segala sesuatu peristiwa dalam karya sastra yang tidak dapat dipisahkan dengan ruang dan waktu. Ruang dan waktu tidak selalu pasti akan tetapi mengalami perubahan sepanjang masa. Keduanya merupakan satu kesatuan yang hadir dan berelasi dengan konteks lingkungan budaya.

Penelitian tentang ruang dan waktu pernah dilakukan oleh Hidayat (2018) tentang Ruang, Waktu, dan Sejarah dalam Novel Boroen dari Digoel menunjukkan hasil bahwa waktu yang dinarasikan merujuk pada masa kolonial antara tahun 1927-1928. Ruang yang dinarasikan merujuk pada wilayah Boven Digul di Papua. Kedua aspek ini mengungkap sejarah pembuangan tokoh sejarah Indonesia ke Boven Digul oleh pemerintah kolonial Hindia Belanda. Pembuangan ini dialami sendiri oleh penulis Boroen dari Digul. Penelitian ini mengungkap ruang, waktu, sejarah yang terepresentasi secara jelas dengan ruang dan waktu tertentu yang sifatnya paten karena ruang, waktu dan sejarah merujuk pada kejadian tertentu. Waktu dalam pengertian di atas dapat diartikan sebagai hidup (time is life) artinya bagi manusia waktu sama saja dengan hidup (Gea, 2005).

Kajian penelitian ini menekankan pada ruang dan waktu dalam perspektif budaya. Hal ini memiliki keunggulan bahwa ruang dan waktu tidaklah stagnan. Keduanya mengalami perubahan ketika ruang dan waktu tersebut berada pada konteks budaya. Ruang dan waktu memiliki kesesuaian dengan berbagai jenis pergerakan materi fisik, geologis, mekanik, astronomis, biologis, sosial historis.

Berdasarkan pemikiran di atas maka penelitian ini akan mengungkapkan representasi ruang dan representasi waktu dalam novel Glonggong karya Junaedi Setiyono. Kedua hal ini penting karena dimensi ruang dan waktu yang diungkapkan dalam novel dalam digali melalui perpektif budaya.

\section{METODE}

Pendekatan penelitian ini menggunakan kualitatif yakni ruang dan waktu dipahami dari lingkungan budaya yang berlaku dalam masyarakat. Metode yang digunakan adalah deskriptif yaitu menggambarkan ruang dan waktu dalam perspektif ekologi budaya. Subjek penelitian adalah novel Glonggong karya Junaedi Setiyono. Data penelitian dikumpulkan melalui analisis teks (novel) dan referensi yang diperoleh melalui jurnal dan buku yang relevan. Analisis data penelitian dilakukan dengan mengklasifikasikan data, mengkategori data serta menemukan persoalan penting terkait dengan kajian ruang dan waktu. Selain itu, ditunjang pula analisis interaktif-dialektis atau bolak-balik untuk melakukan pelacakan terhadap keseluruhan temuan yang diperoleh sehingga keakuratan hasil dapat terjaga. 


\section{HASIL DAN PEMBAHASAN}

Dalam memahami ruang dan waktu dalam sastra naratif diperlukan proses interaksi dengan narator dalam membangun dunia baru dalam bentuk cerita. Ruang dan waktu merupakan bagian penting untuk memahami keseluruhan cerita. Keduanya menopang keberadaan tokoh dalam kaitannya dengan seting, dan alur cerita. Melalui cerita dapat diketahui bagaimana sesungguhnya ruang dan waktu direpresentasikan pada novel Glonggong karya Junaedi Setiyono. Secara keseluruhan persoalan tersebut dibahas pada paparan berikut.

\section{Representasi Ruang dalam Novel Glonggong Karya Junaedi Setiyono}

Persoalan ruang tentunya akan memiliki kesesuaian dengan berbagai jenis pergerakan materi fisik, geologis, mekanik, astronomi, biologis, sosial-historis. Namun, ruang selalu mengalami perubahan mengikuti perkembangan waktu. Dengan dalih 'pembangunan nasional' maka mengakibatkan ruang-ruang tradisional terhimpit keberadaannya oleh modernitas. Kondisi ini dijelaskan Upstone (2016) dalam bukunya Spatial Politics in the Postcolonial Novel menawarkan pembacaan novel-novel pascakolonial yang difokuskan pada bahasan politik ruang. Termasuk di dalamnya pembahasan tentang homogenitas, seperti modernisasi, terhadap kelompok-kelompok tradisional dalam kerangka 'nasionalisme'. Namun yang terjadi dalam novel Glonggong ruang dan waktu sebagai sarana untuk hidup bagi tokoh.

Dimensi ruang dan waktu bagi tokoh tidak dapat dilepaskan dengan budaya masyarakat dimana ruang tersebut menyatu. Hadirnya tokoh aku dalam ruang tertentu menunjukkan bahwa setiap ruang akan sangat tergantung pada penghuninya ketika ingin mengetahui kebiasaan yang dilakukan orang tuannya. Dalam ruang orang dapat berpura-pura dengan berbagai cara untuk mengetahui apa sesungguhnya yang terjadi pada ruang kraton. Budaya laki-laki mengambil selir sesuai dengan pilihannya merupakan sesuatu yang tidak asing dalam ruang kraton seperti pada kutipan berikut.

Bagi tokoh ibu waktu selalu berputar yang tidak seperti dulu. Ketika tokoh aku masih kecil dia tidak boleh memasuki ruang ibuku bersama rama Suwanda. Dengan bergulirnya waktu Rama Suwanda telah memiliki pilihan lain gilirannya ruang yang dulunya bersifat privat ternyata sekarang telah berubah. Hal ini tampak pada peristiwa berikut.

Yang selanjutnya menjadi pertanyaanku adalah mengapa sekarang aku bisa sering masuk kamar ibu untuk mendampinginya menembang. Rama Suwanda sekarang jarang pulang. Bahkan setelah usiaku mendekati sepuluh, sebulan sekali pun belum tentu aku dapat melihat kelebat Rama di rumah (Setiyono, 2007).

Pada usia kurang lebih 10 tahun justru tokoh Glonggong mempertanyakan pada dirinya tentang perubahan yang terjadi pada kehidupan ibu. Bagi anak seusia itu belum selayaknya untuk berpikir tentang kehidupan yang dialami ibunya. Justru pada usia tersebut dalam ruang keluarga seharusnya anak memperoleh perhatian penuh. Namun yang perlu diperhatikan bahwa ibu yang menghuni ruang (rumah) memiliki kebiasaan menembang. Perempuan seperti ibu memiliki keterampilan menembang sebagai tradisi kebiasaan yang ada dalam kraton. Untuk mengalihkan keresahan perasaan maka ibu menembang ketika rama Suwanda sudah jarang pulang. Praktis ketika di rumaah tokoh Glonggong menjadi tumpuhan untuk mendampingi ibu dan menghiburnya agar tidak sedih. Dari sini dapat dikatakan bahwa ruang keluarga tidaklah seharmonis yang dibayangkan tetapi telah berubah karena ada tokoh lain yang membuat ruang baru. Ruang tersebutlah yang membuat ibu menjadi tidak bahagia lagi.

Ruang kraton sebagai simbol kekuasaan tidak dapat dilepaskan dengan keberadaan selir. Ruang digambarkan sebagai sebuah pergulatan yang muaranya pada pemenuhan hasrat kesenangan semata. Tradisi yang berkembang di ruang kraton dengan selir-selir yang dipilih 
sesuai dengan keinginan raja merupakan sesuatu yang biasa. Sebagai seorang anak Glonggong sengaja menelisik apa yang telah terjadi pada ruang yang dihuni ayahnya.

\begin{abstract}
Aku pura-pura tak melihat Rama. Aku yakin dia akan lebih senang kalau aku tak melihatnya. Sebetulnya aku ingin melihatnya lebih jelas wajah perempuan pendamping Rama yang baru, yang tentunya lebih segar dan lebih cantik dibanding ibuku (Setiyono, 2007: 63).
\end{abstract}

Ruang selir merupakan tempat dengan penghuni perempuan yang dipilihnya. Kata lebih segar dan lebih cantik menggambarkan bahwa yang bersangkutan berusia masih muda. Selain itu, masih energik dan dapat memberikan memberikan kepuasan. Hal ini menunjukkan bahwa tradisi di keraton perempuan menjadi penting karena menjadi pendamping pada bendoronya. Zona aksi selalu bergerak untuk pemenuhan ego diri yang tidak dilepaskan dengan waktu. Hal ini sejalan dengan pemikiran Piatti (2008) dalam geografi sastra terdiri lima kategori utama yaitu pengaturan, ruang proyek, zona aksi, marker dan routes. Kategori tersebut terkait dengan perjalanan ruang dan waktu dalam realitas kehidupan yang bermakna. Entitas ruang (rumah) telah mengalami perubahan fungsi sebagai tempat bertemuanya keluarga dengan keakraban telah mengalami perubahan. Ruang tidak lagi memberikan kesenangan dalam konteks keluarga. Sebaliknya ruang membuat penghuninya merasa tidak senang (sedih). Hal ini tampak pada keadaan ibu yang selalu berwajah sendu. Ada sebuah beban yang sengaja disembunyikan oleh Ibu. Ramapun yang seharusnya hidup berdampingan dengan ibu jarang di rumah bahkan bertemu dengan ibu sudah dijadwal. Ruang tidak lagi berfungsi sebagaimana mestinya sehingga menjadikan ruang tersebut penuh dengan pertanyaan yang belum terjawab.

Tak ingat betul mengapa aku tidak betah tinggal lama-lama di rumah. Ketidakbetahanku barangkali karena ibuku. Menurutku ibuku, ibu terlalu pendiam. Ibuku selalu berwajah sendu dengan matanya yang membengkak seperti baru saja menangis. ... Rama yang tak banyak kuketahui, hanya datang kadang-kadang. Datangnyapun tak bisa ditebak kapan. Dan biasanya, dia lebih banyak di kamar bersama ibu. Hampir tak pernah aku bercakap dengannya (Setiyono, 2007: 5).

Ruang sebagaimana didambakan oleh penghuninya yaitu ayah, ibu dan anak untuk berinteraksi dan berkomunikasi mengalami hambatan. Hal ini terjadi karena budaya dalam keluarga untuk membuka diri kurang terpenuhi. Oleh karena itu, ibu sebagai perempuan Jawa memiliki cara tersendiri dalam menghibur diri. Pengalihan suasana ketika seseorang merasakan kesedihan dilakukan dengan menembang. Menembang sebagai salah satu strategi ibu untuk mengalihkan perhatiannya pada perasaan yang kurang menyenangkan. Ibu membuat ruang sendiri agar merasa tenang dalam hidupnya. Hal ini sejalan dengan pemikiran Sugiarti (2010) bahwa ruang memiliki keleluasaan menjamah sesuatu yang berkaitan dengan tempat misalnya: alam yang ada di bumi ini, kota, desa, hutan, masyarakat, pola hidup masyarakat. Menggali konsep ruang lokal dapat terjadi dimana-mana tanpa batas/sekat yang jelas. Ruang ini sepertinya bersifat pribadi bagi ibu dan tempat bersatunya ibu dengan tokoh secara intensif. Ruang dalam budaya Jawa memiliki makna yang misterius karena keberadaan seorang ayah tidak diketahui secara pasti sebagaimana yang dinginkan.

Makin jarang ibu bertemu Rama, makin sering ibu menembang. Dan makin seringlah kami menenggelamkan diri dalam liang kubur yang diciptakan oleh ibuku sendiri Ibuku seorang Raden Ayu dari Daerah Tegalrejo yang menikah 
dengan seorang jagabaya dari wilayah Bagelen. Pernikahan itu tidak berlangsung lama seperti yang dikehendaki para orang tua ... sebabnya ayah raib entah kemana (Setiyono, 2007: 12)

Tokoh Ibu sebagai anggota keluarga terpandang di daerah Tegalrejo menikah dengan seorang jagabaya. Ruang yang berupa lokasi memberikan pemahaman bahwa wilayah tersebut merupakan wilayah yang bertrah kasultanan. Ruang yang semula memiliki makna sakral telah berubah karena tiada kejelasan. Di sisi lain, ruang memberikan segala informasi yang dibutuhkan tetapi ternyata penghuni ruang tidak hadir sehingga ruang tersebut kurang memiliki makna dalam hidup.

Dalam ruang perpustakaan tentunya akan memiliki berbagai pengalaman, pengetahuan yang memadai terkait dengan tugas tersebut. Tetapi bagi tokoh Danar tugas di perpustakaan merupakan tugas yang membawa kehidupannya menjadi nyaman karena ia dapat berkomunikasi dengan orang-orang yang ada di kasultanan.

"Ini dia orang yang akan membawamu ke orang yang kau rindukan. Kata Surya sambil menuntunku masuk ruang perpustakaan. Ternyata orang dimaksudkan adalah orang yang sudah sangat ku kenal. Siapa lagi kalau bukan Kang Danar?" (Setiyono, 2007: 119)

Dalam lingkungan kasultanan ruang menggambarkan perilaku penghuninya. Ada orang tertentu yang bertugas untuk mempertemukan tokoh Glonggong dengan orang tuanya (ayah). Rahasia kasultanan telah dipegang oleh Danar yang dalam kesehariannya ia bekerja di perpustakaan. Ruang dalam hal ini terkait dengan tugas-tugas yang harus dilakukan penghuninya dan budaya yang biasa dilakukan dalam melakukan pelayanan kepada orang lain.

Kata pelarian memiliki makna negatif tetapi jika dihubungan dengan ruang bagi tokoh mampu memberikan pencerahan tersendiri. Perubahan perilaku tokoh dalam hal ibadah disebabkan berada pada ruang yang kondusif untuk berubah. Terjadi proses transformasi spiritual yang dialami tokoh yang disebabkan kesadaran tokoh untuk mendekatkan diri pada Allah sebagai khalifah. Hal ini sejalan dengan pemikiran bahwa akal budinya manusia mampu menjadikan keindahan pencipta alam semesta seluruhnya dan ciptaan kekuasaan-Nya: Dan dialah telah menciptakan bagi kamu sekalian pendengaran, penglihatan dan hati. (Tetapi) sangat sedikit kamu yang bersyukur (QS. Al Mukminun ayat 78). Dalam pandangan tokoh bahwa pelarian merupakan modal untuk memperoleh pengalaman spiritual meski sifatnya masih fisik.

"Pelarianku adalah rumah Suta. Aku jadi rajin ikut mengaji setelah waktu Isya." (Setiyono, 2007: 36).

Ruang dapat mengungkapkan makna yang penting bagi manusia dengan berbagai persoalan yang dihadapinya. Oleh karena itu, ruang dapat membuat suasana nyaman maupun tidak nyaman. Dalam ruang pertemuan seseorang yang telah lama dirindukan menjadi penting. Akan tetapi, ruang penjara membatasi untuk sebuah pertemuan yang menyenangkan karena ruang tersebut memiliki makna negatif. Dalam efek yang paling ujung bahwa warna lokal dianggap memiliki eksotisitas dan kekhasan tersendiri. Oleh karena kekhasannya, ia membutuhkan pemahaman yang mendalam dan memerlukan sejumlah pengetahuan referensial (Sugiarti, 2010). Ruang tersebut telah bergeser pada pandangan yang kurang baik sehingga tidak mau untuk bertemu dengan orang lain kalau hanya menyisakan kenangan pahit. 


\begin{abstract}
"Kau benar-benar ingin bertemu Ki Sena?" Tanyanya perlahan. Wajahnya jadi muram.

"Ya, kalau Ki Sena itu nama ayahku," aku memang tidak tahu siapa nama ayahku. "Dia sekarang mendekam dipenjara Wiragunan. Dia akan merasa dipermalukan dari pada dibahagiakan kau menemuinya." Kang Danar tak mau berlama-lama berbincang soal Ki Sena (Setiyono, 2007: 120)
\end{abstract}

Novel Glonggong mengungkap ruang dalam dimensi yang luas tidak hanya dibatasi pada ruang publik dan privat. Akan tetapi, ruang yang selalu bersimbiosis dengan peristiwa yang berada pada ruang tersebut. Peristiwa dalam ruang memiliki makna yang dalam bagi penghuni ruang tersebut. Penghuni ruang dapat merasa bahagia, sengsara, malu, serta sedih ketika berada di dalamnya. Ruang dalam perspektif ekologi budaya ini tentu saja tidak dapat dilepaskan dari lingkup budaya. Hal ini sejalan pemikiran Zapf (2010) bahwa dalam kerangka ekologi budaya, lingkup budaya manusia saling tergantung dan ditransfusikan oleh proses ekologis dan siklus energi alami. Dengan kata lain, ada ketergantungan budaya pada alam, keberadaan yang tidak terhindarkan dari alam dalam budaya. Artinya, alam dan budaya saling berkelindan satu dengan yang lain. Hal ini sejalan dengan pendapat Saryono (2016) bahwa kebudayaan merupakan pengetahuan manusia yang diyakini kebenarannya oleh masyarakat yang bersangkutan. Selain itu, dalam kebudayaan juga terdapat perasaan-perasaan dan emosiemosi. Kebudayaan menjadi sumber bagi sistem penilaian yang baik dan yang buruk, yang berharga atau tidak berharga.

\title{
Representasi Waktu dalam novel Glonggong karya Junaedi Setiyono
}

Dimensi waktu terkadang dapat dipahami secara nyata tetapi adapula yang harus dipahami secara spiritual. Waktu yang kasat mata yang mudah dipahami tetapi waktu yang tidak tampak itu yang membutuhkan pemahaman mendalam. Dalam konteks ini waktu selalu menyesuaikan dengan dimensi sesuai dengan penggunaannya. Demikian pula bahwa wktu tidaklah tetap tetapi selalu berubah sesuai dengan penempatan waktu. Waktu terus berjalan seperti jarum jam yang selalu bergerak dari satu titik ke titik berikutnya. Waktu tidak dapat dipertegas karena memiliki dimensi yang berubah. Oleh karena itu, ruang dan waktu tanpa ada batas yang pasti karena bersifat statis dan dinamis, mencakup keseluruhan dimensi kehidupan manusia tanpa mengenal batas-batas yang tegas. Hal ini dipengaruhi oleh konstruksi budaya yang disesuaikan dengan gerak mekanis, historis, serta psikologis. Perjalanan waktu yang dirasakan oleh seorang ibu merupakan representasi dalam memahami makna waktu yang sesungguhnya. Waktu telah membawa perubahan secara psikologis terhadap kondisi tokoh.

Di antara tanda-tanda di wajah ibu yang paling aku pahami adalah matanya. Mata itulah wajah ibu sebenarnya. Tanpa melihat matanya aku sulit mengatakan apakah ibu sedang berduka atau biasa-biasa saja. Tak pernah kulihat mata ibu bergembira. Tak pernah kudengar ibu berbicara lama. Seingatku hanya sekali saja ibu berkata-kata padaku dengan cukup panjang dan runut (Setiyono, 2007: 13).

Dalam perjalanan hidup ternyata tokoh ibu mengalami suasana yang tidak menyenangkan karena kehilangan sesuatu dalam hidupnya. Penyemangat hidup tidak tampak dengan ditunjukkan oleh tanda pada matanya yang tidak pernah mereprentasikan kebahagiaan. Waktu telah membawa larut tokoh ibu untuk merenungi kehidupan yang sesungguhnya. Namun sesungguhnya waktu terkait dengan masa lalu ada secercah harapan yang tidak dapat berlangsung cukup lama. Hal ini sejalan dengan pemikiran Llewellyn (dalam Hidayat, 2018) bahwa waktu merupakan siklus (pengulangan) dan monumental (kekekalan). Waktu linear 
waktu yang terkait dengan sejarah, politik, tatanan simbolik, serta catatan resmi. Dalam tatanan simbolis biasanya berupa urutan komunikasi verbal, waktu linear terdiri atas ucapan kalimat masing-masing menjadi urutan kata, memiliki tujuan pesan awal dan akhir.

Waktu terkait dengan peristiwa sejarah terkadang membawa dalam dimensi yang berbeda. Pergulatan peristiwa terkait dengan kondisi masyarakat memberikan pengaruh psikologis secara individu maupun kelompok. Ketika terjadi dentuman meriam maka seluruh masyarakat merasa takut dan berupaya untuk menyelematkan diri dari peristiwa tersebut. Rakyat dihantui perasaan tidak tenang akibat peristiwa tersebut seperti kutipan berikut.

Tidak seperti biasanya, jalan menuju Puri Nyai Tegalreja sudah penuh dengan kerumunan orang. Kekhawatiranku mulai menggendor dada ketika kudengar suara dentuman meriam berkali-kali. Beberapa saat kemudian, asap mulai pekat membubungi langit. "Puri diserang! Puri dibakar!" begitu teriakan-teriakan ketakutan bercampur kemarahan yang terdengar (Setiyono, 2007: 130).

Demikian pula waktu yang terkait dengan peristiwa sejarah. Perang tentunya akan membawa banyak kerugian baik secara material maupun inmaterial. Pada akhirnya rakyat yang akan merasakan akibat peristiwa tersebut. Waktu lebih dapat dimaknai sebagai peristiwa yang membuat orang lain panik untuk menyelematkan diri dari peristiwa perang. Sesungguhnya, waktu tidak dapat diamati tetapi menjadi nyata dan karenanya dapat dilihat dalam berbagai perubahan. Bersama dengan parameter spasial tinggi, lebar, dan kedalaman, waktu adalah dimensi keempat yang memungkinkan untuk menemukan dan mengukur kejadian. Selain gagasan umum ini, waktu dikonstruksi secara budaya, dan dengan demikian konsep waktu berbeda-beda sebagai akibat dari dari evolusi sejarah (Wibowo, 2004).

Hari itu 20 Juli 1825. Dan sejak hari itu mulailah Java Oorlog, perang Jawa. (Setiyono, 2007: 132)

Pembebasan seseorang dari penjara merupakan peristiwa yang ditunggu-tunngu. Dalam pandangan lain pembebasan sebagai aktivitas yang dapat menghirup udara segar di luar tahanan. Orang dapat merasakan kembali hidup bersama keluarga, saudara, serta tetangga dekat. Dalam hal ini seseorang merasa dirinya telah kembali pada kehidupan seperti semula. Hal ini sejalan dengan pemikiran bahwa waktu dalam sastra bisa satu dimensi dan poli dimensi, dinamis dan statis, dapat dikompresi dan diperpanjang dalam teks (Jauf, 2009).

Ki Sena ditahan disini?" tanyaku pada salah seorang penjaga setelah sebelumnya memperkenalkan diri. "Dia sudah dibebaskan hampir sebulan yang lalu." (Setiyono, 2007: 125)

Demikian pula, hidup selalu berputar terkadang kita dapat mengendalikan diri terkadang pula lupa. Segala sesuatu yang sudah lama didambakan akhirnya porak poranda akibat ulah kata yang dilakukan tokoh tanpa adanya kontrol yang baik. Hal ini terkait dengan ketidakmampuan seseorang dalam mengendalikan diri berakibat pada dirinya sendiri.

Aku tak mampu untuk berkata-kata. Mulut ternganga dan mata terbelalak menunjukkan kepada Ki Karta apa yang kurasakan. Benang harapan yang ku pintal berbulan-bulan lamanya sekarang kembali terburai tak tentu ujudnya terburai tak keruan seperti dedaunan yang diaduk angin puting beliung (Setiyono, 2007: 174) 
Penghayatan terhadap keyakinan akan segala peristiwa yang terjadi dalam kehidupan. Hidup sesungguhnya menjalani apa yang telah ditentukan oleh Allah. Semua peristiwa sudah menjadi skenario yang tidak dapat dihindari.

Kehidupan dunia hanya permainan dan senda gurau belaka, janganlah kamu sempat terperdaya olehnya. Inilah salah satu bunyi ayat kitab suci yang mendengung-dengung di telinga saat kulihat para pengikut Kanjeng Sultan berguguran. Apa kurangnya mereka itu? Mengapa Gusti Allah tidak melindungi mereka dari bahaya sehingga pelor kompeni diizinkan-Nya melangga jantung mereka? Ataukah karena sayangnya Gusti Allah pada mereka sehingga mereka dipanggil-Nya segera? Ya, kehidupan dunia memang bisa mempedayakan. Kehidupan setelah mati itulah kehidupan yang sesungguhnya. Begitu kata Kiai Ngali padaku ketika itu (Setiyono, 2007: 180).

Pada kutipan di atas menggambarkan dalam kehidupan manusia memperoleh kesenangan semata namun terkadang lupa memahami hakikat hidup yang sebenarnya. Nilainilai dalam novel disampaikan lewat pembandingan, pelambangan, simbolisasi, karakter, sikap hidup, dan perilaku tokoh yang lebih berfungsi sebagai acuan kultural (Nurgiyantoro, 2019).

Pada dimensi ini manusia secara spiritual diarahkan untuk memahami kehidupan secara holistik. Waktu terus berputar kapan waktu akan berhenti pada diri manusia maka sebaiknya mempersiapkan sedini mungkin sehingga tidak termasuk orang yang merugi dalam kehidupan setelah mati.

Aku gunakan waktu luangku untuk membaca buku yang ku pinjam dari perpustakaan yang berada di satu ruang di rumah utama (Setiyono, 2007: 96).

Waktu diisi dengan sesuatu yang bermanfaat bagi dirinya untuk meningkatkan pengetahuan dan wawasan pemikirian. Proses belajar memang tiada akhir. Dengan waktu itulah manusia dapat mengubah diri menjadi sesuatu yang positif. Ada kesadaran tokoh untuk mengubah diri dengan terus memburu informasi melalui bacaan. Permulaan orang yang tidak bisa membaca dan menulis maka ia selalu berupaya untuk melakukannya seperti kutipan berikut.

Sejak saat itu aku mulai membaca huruf latin. Aku mulai melafalkan kata demi kata. (Setiyono, 2007: 99)

Proses belajar yang dilakukan tokoh aku sebagai bentuk kesadaran menghargai waktu untuk kepentingan membaca dalam rangka memahami sesuatu yang ada di sekitarnya. Dengan membaca orang akan mengetahui berbagai informasi. Melalui bacaan itulah manusia akan mengenal dunia dengan berbagai informasi yang tersedia. Pentingnya orang menguasai pengetahuan sebagai gambaran bahwa manusia mampu memikirkan sesuatu yang ada dalam kehidupan ini. Budaya literasi melalui kegiatan membaca menjadi penting. Melalui kegiatan membaca akan membawa konsekuensi logis pada pemahaman dan perluasan pemikiran.

Kekuatan lingkungan budaya serta peristiwa-peristiwa yang dialami tokoh merupakan sesuatu pengalaman yang unik dan menarik. Perpaduan antara batiniah tokoh dengan penyatuan dirinya terhadap lingkungan budaya menjadikan keyakinan tersendiri bagi tokoh. Hal ini sejalan dengan pemikiran tentang spiritualitas dalam psikologi (Shofa, 2019). Manusia selalu terikat dengan ruang dan waktu dalam kehidupannya. Meski ruang dan waktu memiliki makna yang berubah dalam dualisme dunia. 
Hal ini berbeda apabila mencermati penelitian tentang Eskapisme Realitas dalam Dualisme Dunia Alice Telaah Psikologi-Sastra Film Alice In Wonderland yang dilakukan oleh Andalas (2017), sebagai bentuk cerita fantasi yang dapat dijelaskan secara logis, cerita ini merefleksikan mengenai bentuk pelarian dari realitas kehidupan ke dalam dualisme dunia yang sangat berbeda, yaitu nyata dan fantasi. Alice melarikan realitas kehidupannya dalam bentuk transformasi tokoh nyata ke dalam tokoh fantasi dalam dunia imajinernya karena dalam dunia imajinernya ia mampu menciptakan, mengatur, dan menentukan jalan cerita kehidupannya. Dunia imajiner yang diciptakannya (Wonderland) merupakan bunga mimpi yang hadir dari ketaksadarannya yang berasal dari akumulasi pengalaman dan pengetahuannya ketika hidup di dunia nyata (Andalas, 2017).

Berdasarkan pemikiran yang telah diungkapkan di atas dapat dikemukakan bahwa representasi ruang dan waktu dipengaruhi oleh cara pandang pengarang dalam memahami tentang lingkungan budaya. Hal ini tampak pada cara berpikir dan perilaku tokoh dalam narasi cerita. Keberadaannya tidak dapat dideteksi secara pasti karena kemungkinan adanya perubahan-perubahan sejalan dengan perkembangan yang ada. Di samping itu, keduanya tidak dapat dilepaskan dengan budaya setempat dalam memahami dan menghayati keberadaannya yang bersifat adaptif.

\section{SIMPULAN}

Representasi ruang mengarahkan pada sebagian tempat yang dibatasi oleh space yaitu ruang publik dan ruang privat yang selalu berubah. Ruang menyatu dan bersinergi membangun karakter tokoh secara keseluruhan yang menyaran pada pengetahuan dan pengalaman tokoh. Representasi waktu berdimensi tidak tetap/stagnan sehingga selalu terjadi perubahan. Waktu mampu menyingkap kerahasian hidup yang bersifat mistis. Ruang dan waktu tidak pernah dianggap sebagai bentuk-bentuk murni atau bentuk kosong. Ia akan selalu berinteraksi dengan komunitas yang bergulir dan bersifat dinamis.

\section{DAFTAR PUSTAKA}

Andalas, E. F. (2017). Eskapisme Realitas dalam Dualisme Dunia Alice Telaah PsikologiSastra Film Alice in Wonderland (2010). KEMBARA: Jurnal Keilmuan Bahasa, Sastra, dan Pengajarannya, 3(2), 185-195.

Bardara, A. (2012). Analsis Wacana Teori, Metode, dan Penerapannya pada Wacana Media. Jakarta: Kencana Pernada Media Group.

Gea, A. A. (2005). Character Building IV, Relasi dengan Dunia Alama, Ipteks, dan Kerja. Jakarta: Media Elex Komputindo.

Hidayat, A. R. (2018). Waktu, Ruang, dan Sejarah dalam Novel Boeron dari Digoel SAWERIGADING, 24(1), 65-72.

Jauf, H. R. (2009). Zeit und Erinnerung in Marcel Prousts "À la Recherche du Temps Perdu." Ein Beitrag zur Theorie des Romans. Frankfurt Suhrkamp.

Nurgiyantoro, B. (2019). The Wayang Story in Modern Indonesian Fictions (Reviews on Mangunwijaya and Sindhunata's Novels). LITERA, 18(2), 167-184.

Piatti, D. (2008). I Confidi Gestione Delle Garanzie, Redditività e Pricing. Turin: Bancaria Editrice.

Ratna, N. K. (2011). Antropologi Sastra: Peranan Unsur-Unsur Kebudayaan dalam Proses Kreatif. Yogyakarta: Pustaka Pelajar.

Saryono, J. (2016). Pendekatan Multikultural dalam Pembelajaran Bahasa dan Sastra Indonesia. Paper presented at the Seminar Nasional Membina Karakter Manusia Berbudaya Menuju Bangsa yang Berkemajuan Melalui Pembelajaran Bahasa dan Sastra Indonesia, Malang. 
Setiyono, J. (2007). Glonggong. Yogyakarta: Serambi.

Shofa, I. R. (2019). Representasi Konsep Ketuhanan: Analogi Cerita dalam Novel Semua Ikan di Langit karya Ziggy Z. Pena Literasi, 2(1), 147-156.

Sugiarti. (2010). Representasi Kelokalan dalam Novel Petir Karya Dewi Lestari Paper presented at the Seminar Nasional Bahasa Ibu III yang diselenggarakan Program Studi Magister dan Doktor Linguistik Program Pascasarjana Universitas Udayana, Bali.

Sugiarti. (2013). Representasi Konteks Sosial Novel 200-an dan Sumbangannya terhadap Kesusasteraan Indonesia. Hasil Penelitian Fundamental: DPPM Universitas Muhammadiyah Malang.

Upstone, S. (2016). Spatial Politics in the Postcolonial Novel. Lodon: Routledge. Wibowo, A. S. (2004). Gaya Filsafat Nietzsche. Yogyakarta: Galang Press.

Zapf, H. (2010). Ecocriticism, Cultural Ecology, and Literary Studies. New York: Longman. 